\title{
DEVELOPMENT OF A LEAFY CROPS HARVESTER
}

\section{S. M. Younis ${ }^{1}$, M. S. Omran' ${ }^{2}$ T.H. Mohamed ${ }^{3}$, M.A. Amer ${ }^{4}$}

\section{ABSTRACT}

Leafy crops harvester prototype was modifying depending on the leafy crops characteristic like crop height leaves surface area crop stems. The prototype included frame, conveyor, collection box, and transmission system. Results provided the suitability of the modifying prototype to transportation and collecting leafy crops, the suitability of the modifying prototype was judged through the removal percentage, un-damaged percentage and losses percentage.

\section{INTRODUCTION}

egetable is an important class of agricultural products at the
national and international levels. They present core products
that contribute to main food and drugs. The economy of the leafy vegetable e.g. spinach, parsley, basil, dill, cabbage, celery, lemon grass, baby spinach and thyme has been growing during the last decades due to the increasing demand to industry. The national production of leafy vegetables in the years of 2010 was 37000 tons. Parsley represents an example of economically important leafy crops. Parsley has many benefits and uses in the area of health and drugs. It has culinary uses seems to help blend other flavours. It ameliorates strong odours like garlic and fish. It works well with most foods except sweets, Medicinal Uses: parsley can also provide dietary sources of calcium $(\mathrm{Ca})$, potassium $(\mathrm{K})$, phosphorus $(\mathrm{P})$, magnesium $(\mathrm{Mg})$, and iron (Fe), as well as vitamin $\mathrm{A}$, vitamin $\mathrm{C}$, and carotenoids (Rademaker, 2007). It is not worthy to mention that some medical Egypt companies produce some drugs from parsley. Mean while an important economic value of parsley is the exportation to international markets. One of the most important factors that guaranties good quality of the vegetable product is high performance of the harvesting techniques.

\footnotetext{
${ }^{1 .}$ Prof., Agric. Eng. Dep., Fac. of Agric., Cairo Univ.

2. Associate Prof., Agric. Eng. Dep., Fac. of Agric., Cairo Univ.

3. General Director of the Need and Experiments. Agric. Res. Center.

4. Agric. Engineer, Agric. Eng. Res. Institute.
} 
This can aid in better competition for the international market and in reaching the international standards for the quality of those leafy crops. Parsley is locally harvested by manual technique and yet the mechanical methods are not widespread in Egypt. Current problems associated with the manual processes include unstable labor availability, high cost for labors and possible healthy problem, regarding transfer of diseases from labors to the end users.

Hanna and Suliman (1986) mentioned that the scythes and sickles have simply remained largely the same for literally thousands of years. They also added that the efficiency of hand tools, at best they place heavy demands, on human energy, increase work hours and are often responsible for low levels of production and increasing reluctance of labors to work in agricultural sectors.

Hegazy, et al. (2011) designed a new harvesting prototype for cutting and collecting different types of aromatic and medical plants. They showed that the main components of the experimental harvester are: engine with travelling mechanism, cutting unit and conveyor unit connected with storage tank. The design concepts were related to cultivation, environmental factors for these types of plants. The others observed that, The general performance of the prototype for harvesting three types of aromatic and medical plants showed that the working time taken by the machine to collect sage was higher than the time taken to collect rosemary and winter savory by 16 and $12 \%$, respectively, where average values of fuel consumption for sage, rosemary and winter savory were $0.32,0.27$ and $0.30 \mathrm{~kg} \mathrm{kWh}^{-1}$, respectively. Machine working efficiency varied from 28.5 to $36.9 \mathrm{~m}^{2} \mathrm{~min}^{-1}$ for all plants. Best working efficiency value obtained by using machine with rosemary. There were increasing in harvesting losses for sage and rosemary by 15.4 and $14 \%$ compared to winter savory, also number of transferred plants in case of winter savory was high and gave best transfer efficiency by $89.2 \%$.

Celik (2006) tested a cutter bar mower for harvesting it wae mainly consisted of six main components including the cutting, transmission, power, handling, frame, and transporting units. A two cycle engine that produced $1.47 \mathrm{~kW}$ at $7000 \mathrm{rpm}$ provided power for the cutting unit. Two skids were attached to the cutter bar unit, one on each side, to control 
cutting height. The total mass of the mower was $41 \mathrm{~kg}$. He resulted that, the effective field capacity $0.11 \mathrm{ha} / \mathrm{h}, 10 \mathrm{~L} / \mathrm{h}$ fuel consumption, 0.875 field efficiency, $2.24 \mathrm{t} / \mathrm{h}$ effective wet grass harvesting capacity, $4.43 \mathrm{~L} / \mathrm{t}$ wet grass specific fuel consumption, and $64 \mathrm{~mm}$ cutting height.

The aim of the present work is to develop a common reciprocated mower to mechanize the harvesting of locally produced leafy crops. This will help to get advantage of better performance, higher quality of the harvested vegetables and lower the cost at the whole harvesting process. One of the expected results is to spread this approach locally and to increase the possibility of exportation of leafy crops.

To achieve the objective it was required design and manufactures a belt conveyor attached behind the cutter bar of a side reciprocating.

\section{MATERIALS AND METHODS}

The designed conveyer transfers the harvested leafs to a collecting box located behind the tractor. This development needs to design and modify the transmission system to transmit the motion to the conveyer.

The plan of realizing the objective of this research was implemented through the following steps:-

(a) Determine some physical and mechanical characteristics of leafy crops.

(b) Select a common mower which has high productivity, simple design and suitability for cutting leafy crops.

(c) Test the original mower for determining the field performance parameters and its effect on the leafy crops.

(d) Modification of steps to equip the original mower with crop transportation unit and collection box.

(e) Evaluate the developed mower technically and economically and make the required manipulation.

\section{Original mower:}

The original mower was one of the common mowers used to harvest leafy crops. Figure (1) shows the components of the selected mower. The original machine was a mower equipped with $180 \mathrm{~cm}$ cutter bar width with double reciprocating blades with knife spacing $7.6 \mathrm{~cm}$. 


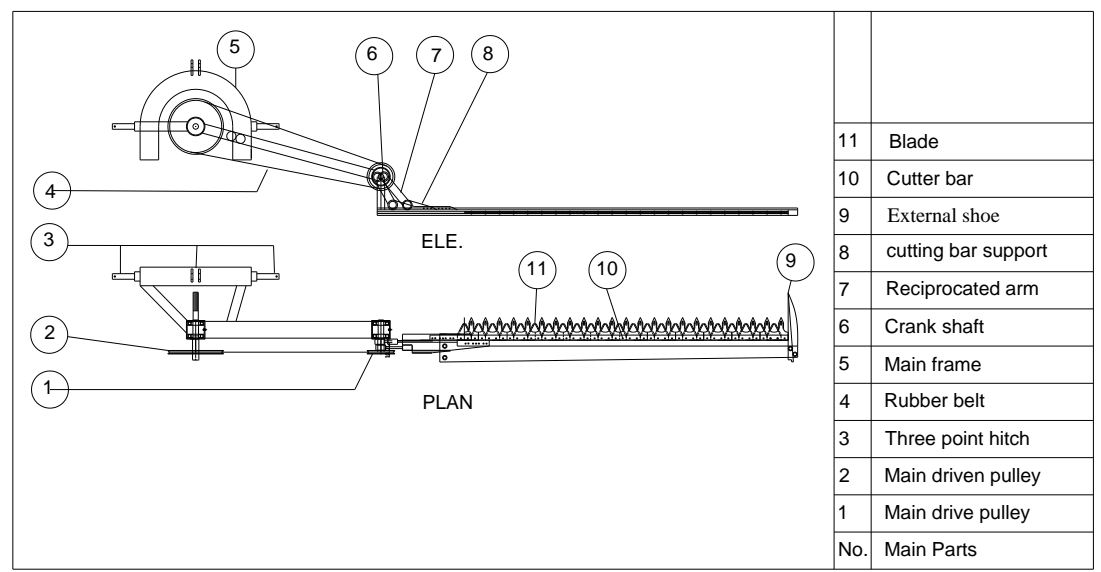

Fig. (1): The components of the original mower

The motion was transferred to cutter bar from the tractor power take off via universal joint at $540 \mathrm{rpm}$. A pulley of diameter $30 \mathrm{~cm}$ transform the motion directly from the universal joint and submits it to a pulley with diameter of $15 \mathrm{~cm}$ via rubber belt.

The developed mower:

A conveyer belt was attached to the original mower through extra frame. The conveyer belt transfers the harvested leafs from the outer mower's shoes to a collection box located behind the tractor at the distance between the rear wheels. This development secures harvesting leafy crops in a clean and well controlled system to suit the different condition of harvesting.

The modification was developed through three sub systems which are transportation, collection box and transmission system there were fabricated in Meet Khalaf workshop - Agricultural Engineering Unit Ministry of Agriculture.

Leaf transportation system:

The leaf transportation system consisted of the following parts:-

a) Conveyer's frame:-

This frame was designed in order to keep enough stretching of the conveyor belt the conveyer's frame was manufactured from right angel steel $4 \times 4 \mathrm{~cm}$ with thickness of $0.3 \mathrm{~cm}$ and Carbon steel sections 
$14 \times 5 \times 0.4 \mathrm{~cm}$. all attached to the cutter bar with two plate steel having cross section of $5 \times 0.4 \mathrm{~cm}$ for each.

b) Conveyer:

The conveyer was made of special plastic three ply rating and it was equipped with notched surface. The conveyer dimensions were $(175 \times 70$ $\mathrm{cm})$. Both ends of the conveyer were welded with laser ray by special instrument.

c) Drive and Driven drum:

Figure (2) shows the drive and driven drum and its components. The idler drive was made of steel pipe with diameter of $14 \mathrm{~cm}$ thickness of $4 \mathrm{~mm}$ and length of $100 \mathrm{~cm}$. Two flanges with diameter of $15 \mathrm{~cm}$ were welded at both edges of the drum to prevent the conveyer to slip. An axle of diameter $3.5 \mathrm{~cm}$ was fixed along the center of the drum and welded out of the two flanges. The drive drum axle was rolled on two ball bearing housing equipped with double ball bearing. The bearing housing was equipped with threaded bolt to adjust the tension of the conveyer. The motion was transferred to the drive drum via a pulley fixed at the end of the axle.

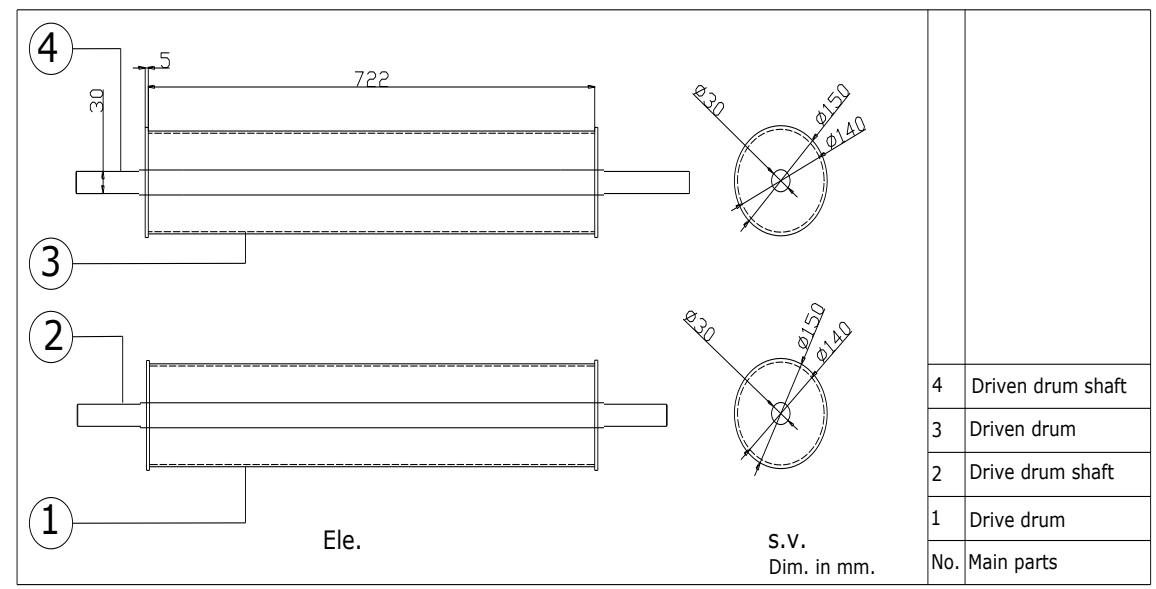

Fig. (2): The dimensions of the drive and driven drums

d) Collection box:

A Collection box made of steel sheet $0.2 \mathrm{~cm}$ thickness, length of $150 \mathrm{~cm}$, width 80 and height $5 \mathrm{~cm}$ was fitted behind the mower between tracks of the tractor. 
Transmission system:

It was necessary to transmit motion to the conveyer through a simple system. A pulley of $25 \mathrm{~cm}$ diameter was fixed on the same axel of the main original pulley. The pulley was rotated on $540 \mathrm{rpm}$. The motion was transferred to the idler drum through another pulley with $150 \mathrm{~mm}$ diameter via reversible rubber belt. Figure (3) shows the transmission system after development.

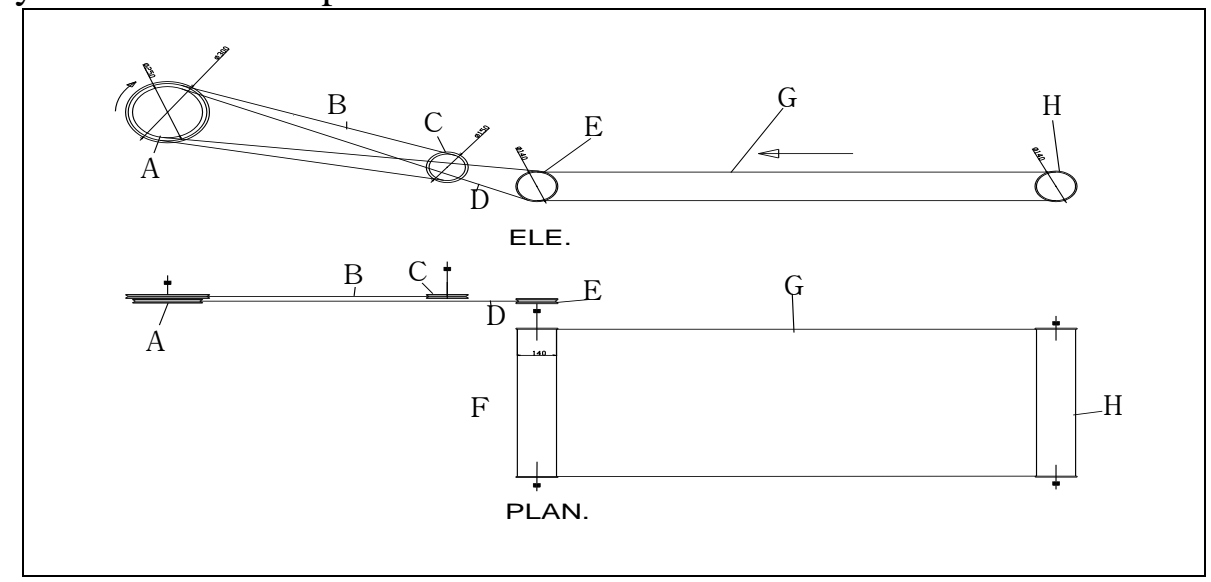

Fig (3): A schematic of transmission system after development

(A)Double drive pulley (B) Belt (C) Cutter bar pulley (D) Reversible belt (E) Driven pulley (F) Drive drum (G) Harvesting conveyer (H) Driven drum

The overall features of the developed mower are shows in Figure (4).

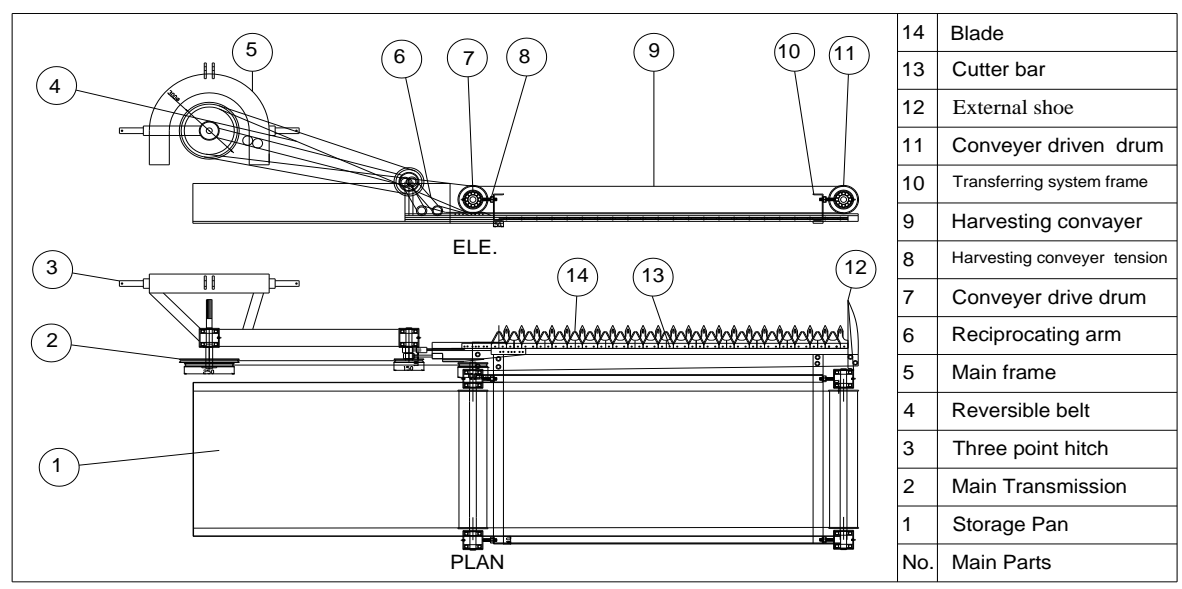

Fig (4): The mower after development 


\section{$\underline{\text { Tractors: }}$}

A Kubota tractor model M 9000, 90 hp engine at 540 r.p.m., was used to operate the modified machine with $150 \mathrm{~kg}$ front weight. The tractor was equipped with narrow tires. Four forward speeds were selected during the experiments. The speed was adjusted and stabilized with assistance of fuel hand control lever.

\section{Design methodology:}

1. Evaluate the performance of the machine to be developed to determine the developed elements.

2. The development of the machine functional and its components manufactured and tested.

3. Evaluation of the model developer technically and economically.

4. Testing the developed machine of some leafy crops,

\section{2-5: Measurements and calculation:}

The design of the component-units of the machine was carried out putting into consideration, the specific functions of each component units. The main units are: the conveyor, power requirement and the operating capacity.

- Machine flied capacity $(\mathrm{Fc})$

$F c=A / t$ Actual field capacity was calculated as follows:-

Where:

$F c=$ Felid capacity, feddan/h;

$\mathrm{A}=$ Harvested area, feddan;

$\mathrm{t}=$ Machine operating time, $\mathrm{h}$.

- The pulley diameter

$D=\frac{d s}{V}$

Where:

$\mathrm{D}=$ Diameter of driven pulley, $\mathrm{mm}$.

$\mathrm{d}=$ Diameter of driving pulley, $\mathrm{mm}$.

$\mathrm{V}=$ Speed transmitted to driven pulley, $\mathrm{mm} / \mathrm{sec}$.

$\mathrm{s}=$ Speed if driving pulley, $\mathrm{mm} / \mathrm{sec}$. 
- Conveyer speed:-

The conveyer speed was calculated by using the following formula:

$\frac{N_{1}}{N_{2}}=\frac{D_{2}}{D_{1}}$

Where,

$N_{1}=$ First pulley speed, rpm;

$N_{2}=$ Second pulley speed, rpm;

$D_{1}=$ First pulley diameter, $\mathrm{mm}$;

$D_{2}=$ Second pulley diameter, $\mathrm{mm}$.

Table (1): The drive and driven pulley diameter

\begin{tabular}{|c|c|c|c|}
\hline $\begin{array}{c}\text { Diameter (A) } \\
(\mathrm{mm})\end{array}$ & $\begin{array}{c}\text { Diameter (E) } \\
540 \mathrm{rpm}\end{array}$ & $\begin{array}{c}\text { Drive drum } \\
\text { (rotary speed) } \\
\mathrm{rpm}\end{array}$ & $\begin{array}{c}\text { Conveyer } \\
\text { linear speed } \\
\mathrm{m} / \mathrm{s}\end{array}$ \\
\hline 250 & 150 & 900 & 3.53 \\
\hline 250 & 180 & 750 & 2.94 \\
\hline 150 & 180 & 450 & 1.76 \\
\hline 150 & 250 & 324 & 1.27 \\
\hline
\end{tabular}

- Cutting efficiency:

Cutting efficiency was calculated by using the following formula according to Hanna and Suliman (1986) as follow:

$E_{c}=\frac{H_{a}-H_{b}}{H_{a}} * 100$

$E_{c}=$ Cutting efficiency, $\%$;

$H_{a}=$ Height of plant stands above the soil before cutting, $\mathrm{cm}$;

$H_{b}=$ Height of stubble after cutting (height of cut), $\mathrm{cm}$.

- $\quad$ Power requirement

The following formula was used to estimate the engine power according to Embaby (1985)

$E . P=F C\left(\frac{1}{60 * 60}\right) P . F * L C V * 427 * \eta_{t h} * \eta_{m} * \frac{1}{75} * \frac{1}{1.63}, k W$

Where: 
$\mathrm{Fc}=$ The fuel consumption, $\mathrm{L} / \mathrm{h}$.

$\mathrm{P} . \mathrm{F}=$ The density of fuel, $\mathrm{kg} / \mathrm{L}$ (for solar $=0.85$ ).

L.C.V =The lower calorific value of fuel (k.cal $/ \mathrm{kg}$ ) average L.C.V of solar is $10000 \mathrm{k} . \mathrm{cal} / \mathrm{kg}$ ).

$\eta_{\text {th }}=$ The thermal efficiency of the engine, consider to be about 40 percentage for diesel engine).

$427=$ Thermo-mechanical equivalent, $\mathrm{kg} \cdot \mathrm{m} / \mathrm{kcal}$.

$\eta_{\mathrm{m}}=$ The mechanical efficiency of the engine, consider to be 80 percentage for diesel engine).

Power requirement $=3.16 \mathrm{Fc}, \mathrm{kW} / \mathrm{h}$.

So, the energy requirement in $(\mathrm{kW} . \mathrm{h} / \mathrm{fed}$.$) , was calculated as$ follows

Engerey requirment $=\frac{\text { the required power }(\mathrm{kw})}{\text { actual fild capacity }\left(\frac{\text { feddan }}{h}\right)}, \mathrm{kW} \cdot \mathrm{h} / \mathrm{feddan}$

- Economical evaluation:

The economical evaluation of the developed mower was based on a group of parameters. These parameters were tractor and harvesting operating costs, Internal Rate of Return (IRR), Net Present Value (NPV) and Pay Back Period (PBP) were used to evaluate the benefit of the developed mower

\section{Operation costs:}

The tractor and mower operating costs were calculated from following equation according to Oida 1997. These costs include depreciation (D), annual capital interest $(I)$ taxes, housing and insurance (THI), repair and maintenance $(R)$, fuel cost $(F)$, oil cost $(O)$ and labor cost $(L)$

$$
\begin{aligned}
& \text { TC } \\
& =\frac{\left\{\left[\left(\frac{P C-S V}{Y}\right)+\left(\frac{P C+S v}{2} * \frac{i}{100}\right)+0.02 P c\right]+\left[\left(\frac{P C * r_{c}}{Y}\right)+(0.25 P t * f c)+(O c * c * n)+(N * L * n)\right]\right\}}{n} \\
& T c \quad=\text { Total cost } \\
& P_{c} \quad=\text { Purchase price } \\
& S v \quad=\text { Salvage value } \\
& =0.56(0.885)^{Y} * P_{c} \text { for machine. } \\
& =0.68(0.920)^{Y} * P_{c} \text { for tractor. } \\
& i \quad=\text { Interest rate } \quad \% \text {; } \\
& r_{c} \quad=\text { Coefficient of repair and maintenance }=0.80 \quad \text {, decimal; }
\end{aligned}
$$




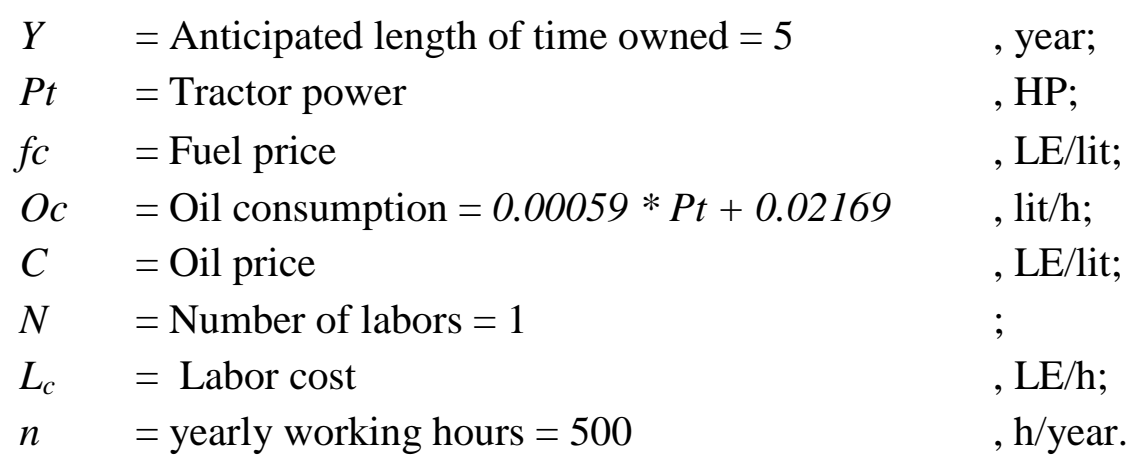

\section{RESULTS AND DISCUSSION}

1. Dimensional characteristics of Parsley:

The results showed that the maximum frequency of the crop height was $310 \mathrm{~mm}$ and the minimum frequency was $110 \mathrm{~mm}$ and the majority has a height in rang 230- $270 \mathrm{~mm}$, Figure (5) showed frequency of the taken measurements of the crop height.

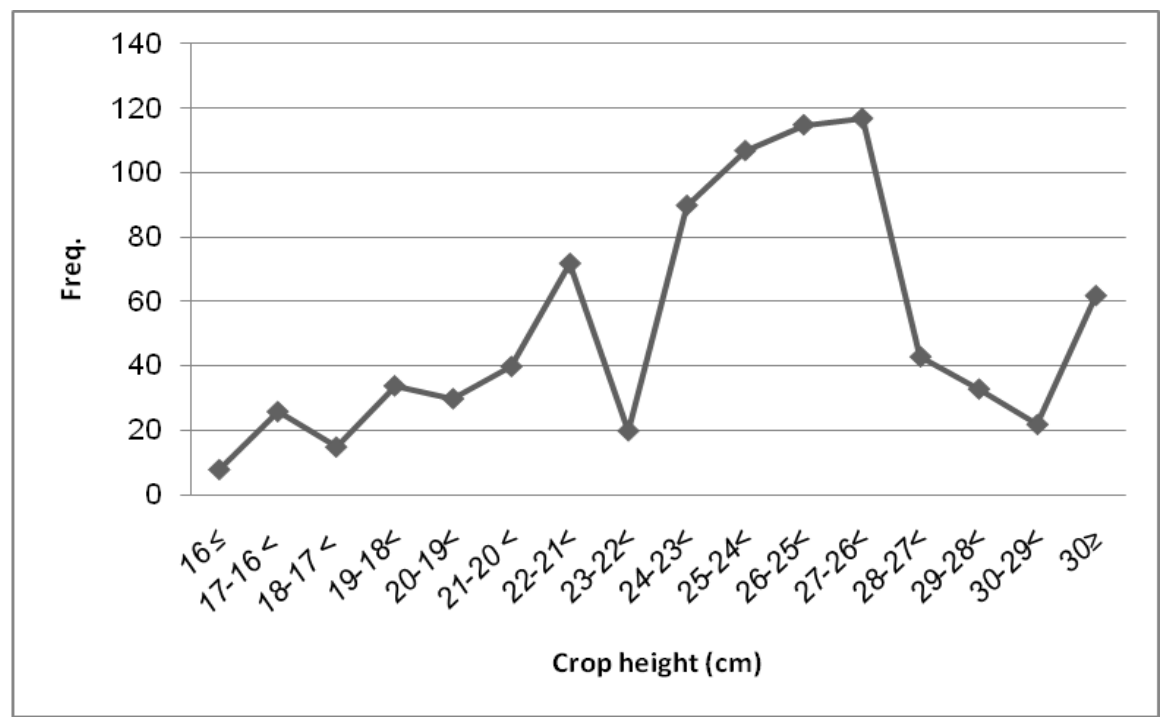

Fig (5) show frequency of the taken measurements of the crop height

Also, the results show that the maximum frequency of the crop stems cross section was $\geq 0.5 \mathrm{~mm}$ and the minimum frequency was $\leq 0.1 \mathrm{~mm}$ and the majority have a stem in the rang 0.2- 0.3mm, Figure (6) show frequency of the taken measurements of the stem diameter. 


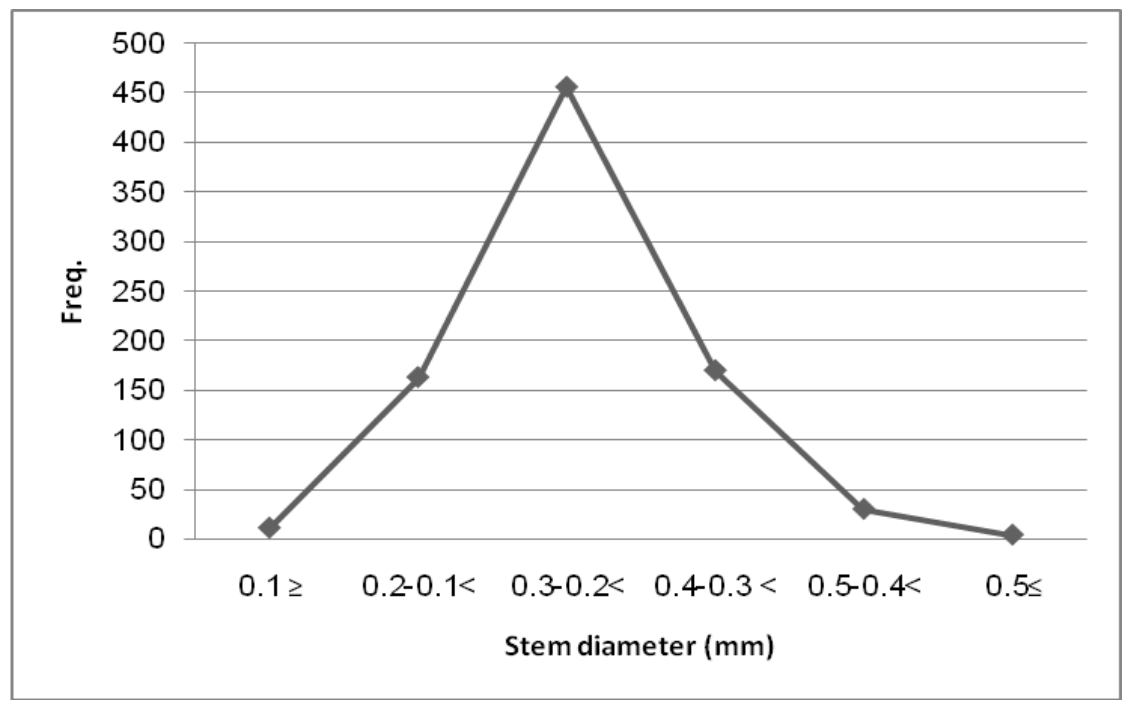

Fig (6) show frequency of the taken measurements of the stem diameter.

The maximum value of the leaves surface area was $\geq 23 \mathrm{~mm}^{2}$. While the minimum value of the leaves surface area was $\leq 10 \mathrm{~mm}^{2}$ and the majority of leaves have surface area $10-14 \mathrm{~mm}^{2}$, Figure (7) show Frequency of the taken measurements of the leaf surface area.

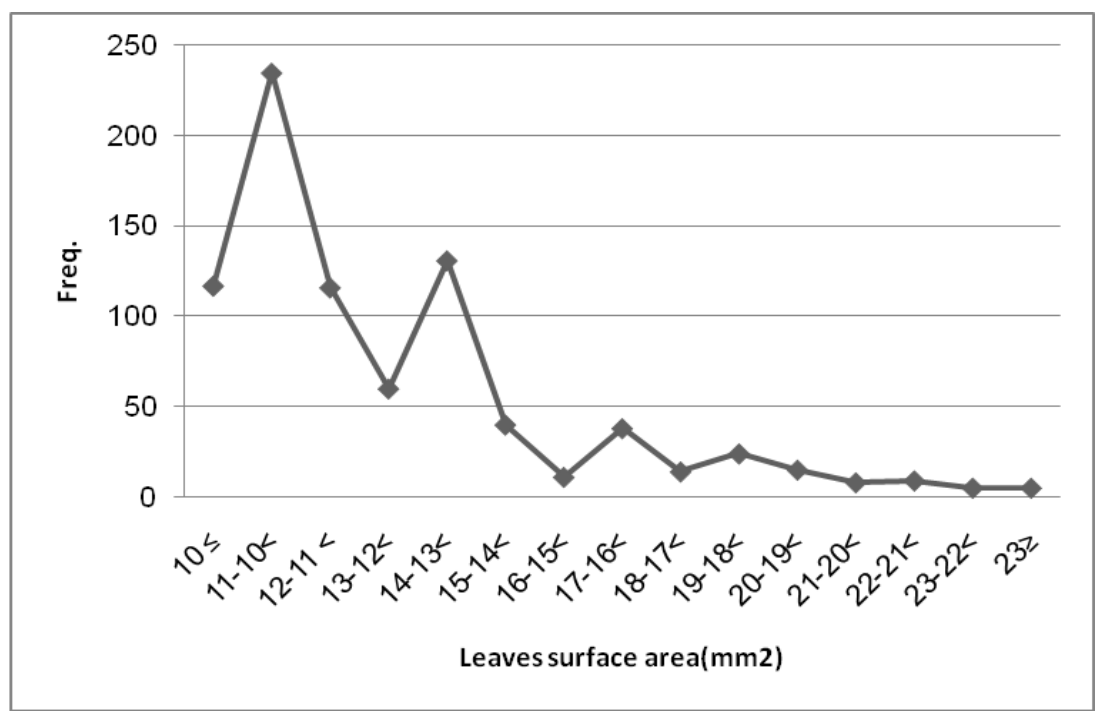

Fig (7): Frequency of the taken measurements of the leaf surface area.

It was realized in the field that the plant dimension was differ from place to other in the same field and other fields according to the agricultural practices. 
2. Performance of the developed mower:

The procedure of testing the modified mower was as the following steps:1.Testing the developed mower at the same forward speeds that compared with the original machine by changing the tractor selected gearbox lever.

2.Each conveyer speed was tested at four forward speed by changing the speed ratio by changing the conveyer's drive and driven pulleys.

3.Determine the field capacity at the same conditions.

1- Field capacity:

The developed mower was used to harvest parsley at four different conveyer speeds and four forward speeds Figure (8) showed the relation between Forward speed and field capacity in different conveyer linear speed.

The results showed that there is no relationship between the conveyor speed and the average field capacity. The field capacity of the original machine was near to the field capacity of the modified machine at the same selected gear.

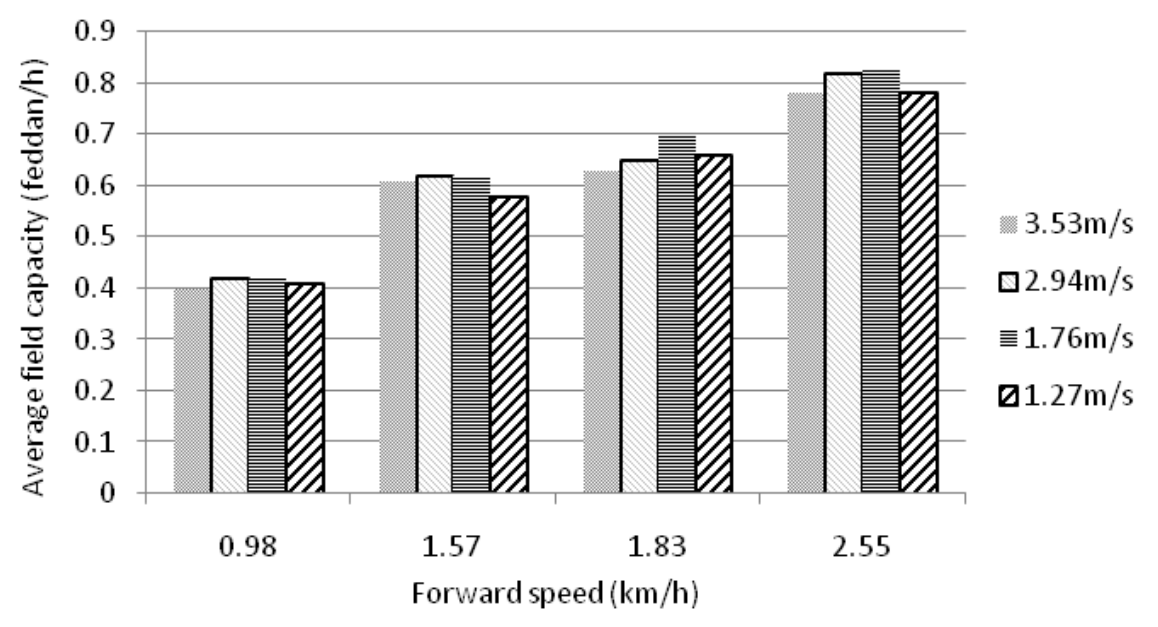

Fig (8): The relation between Forward speed and field capacity in different conveyer linear speed. 
The results showed that the mower forward speed directly proportional to the field capacity.

At conveyor linear speed $3.53 \mathrm{~m} / \mathrm{s}$ and forward speed $1.38 \mathrm{~km} / \mathrm{h}$ and 2.55 $\mathrm{km} / \mathrm{h}$, high losses of the crops behind the conveyor, at the conveyor linear speed $2.94 \mathrm{~m} / \mathrm{s}$ and forward speed $2.55 \mathrm{~km} / \mathrm{h}$, high losses of the crops behind the conveyor, were noticed to justify refusing this working speed were recorded, recommending to perform cutting operation at the forward speed.

It was also realized when using a conveyor speed at $1.27 \mathrm{~m} / \mathrm{s}$ the harvested leafs began to contend and cause clogging on the conveyor.

On the other hand, at the conveyor linear speed $1.76 \mathrm{~m} / \mathrm{s}$ and forward speed $1.83 \mathrm{~km} / \mathrm{h}$ and $2.55 \mathrm{~km} / \mathrm{h}$ recorded the best results to perform the cutting operation.

\section{2- Cutting efficiency:-}

The harvest stem were checked after harvesting with the modified mower to determine the cutting efficiency. Figure (9) showed the relation between cutting efficiency and forward speed for the modified mower

The results showed that there was no relationship between the conveyor speed and the average cutting efficiency. The cutting efficiency of the original machine was near to the cutting efficiency of the modified machine at the same selected gear.

The results showed that the mower forward speed directly proportional to the cutting efficiency Also, at conveyor linear speed $(3.53 \mathrm{~m} / \mathrm{s}, 2.94 \mathrm{~m} / \mathrm{s}$, $1.76 \mathrm{~m} / \mathrm{s}$ and $1 . .27 \mathrm{~m} / \mathrm{s}$ ) and forward speed $2.55 \mathrm{~km} / \mathrm{h}$, high losses of the crops by cutting, were recorded, recommending to perform cutting operation at high forward speed.

On the other hand at the conveyor linear speed $(3.53 \mathrm{~m} / \mathrm{s}, 2.94 \mathrm{~m} / \mathrm{s}$, $1.76 \mathrm{~m} / \mathrm{s}$ and $1.27 \mathrm{~m} / \mathrm{s})$ and forward speed $(0.98 \mathrm{~km} / \mathrm{h}, 1.57 \mathrm{~km} / \mathrm{h}$ and $1.83 \mathrm{~km} / \mathrm{h}$ ) recorded the best result to the cutting operation. 


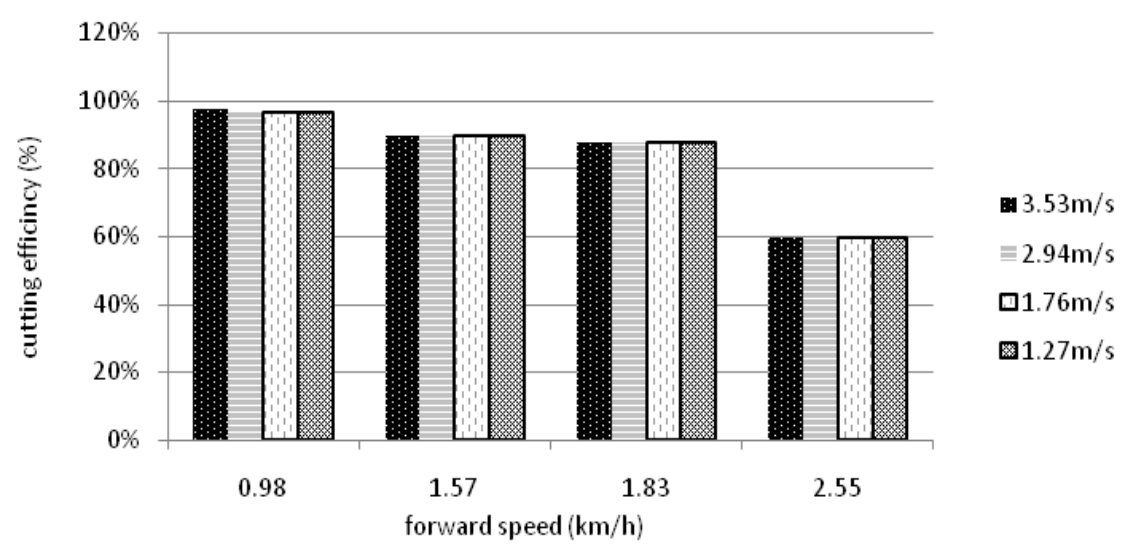

Fig. (9): The relation between cutting efficiency and forward speed for the modified mower

\section{Operation cost}

The calculation of the operating costs included fixed and variable costs were made for tractor and the machine. Applying the input data in Table (2) to Microsoft office software (Excel 2003), the total operating costs for a $50 \mathrm{hp}$ tractor and original mower were $38.9 \mathrm{LE} / \mathrm{h}$ On the other hand, the total operating costs for A $90 \mathrm{hp}$ tractor and developed mower were 45.4LE/h.

Table (2).Items of developed mower costs:

\begin{tabular}{|c|c|c|}
\hline Item & Machine & Tractor \\
\hline Purchase price & 17000.00 & 75000.00 \\
\hline Inflation ratio & 1.00 & 1.00 \\
\hline $\mathrm{Hp}$ & & 90.00 \\
\hline Salvage value & 30.40 & 29.54 \\
\hline Life & 2500.00 & 10000.00 \\
\hline Repair percentage & 60.00 & 100.00 \\
\hline Depreciation & 4.73 & 5.28 \\
\hline Interest & 3.16 & 2.63 \\
\hline Interest value & 14.00 & 14.00 \\
\hline Other ownership costs & 0.68 & 0.75 \\
\hline Fixed costs & 8.57 & 8.66 \\
\hline Repair and maintenance costs (L.E) & 4.08 & 7.50 \\
\hline Fuel cost $\quad$ (L.E) & & 5.72 \\
\hline Lubrication & & 0.86 \\
\hline Labor cost & 5.00 & 5.00 \\
\hline Variable costs & 9.08 & 19.08 \\
\hline Total costs $/ \mathrm{h}$ & 17.65 & 27.74 \\
\hline
\end{tabular}

By using formula the total operation cost was:

\begin{tabular}{|l|l|l|}
\hline Total operation $\operatorname{cost} / \mathrm{h}$ & & 45.4 \\
\hline
\end{tabular} 


\section{SUMMARY AND CONCLUSION}

The Development of leafy crops harvester was made through designing and manufacturing a conveyor behind the cutter bar of a common reciprocating side mower to collect the leafs in a box. Those modifications were made to increase performance of the harvesting process of leafy crops rather than manual harvesting; this resulted in an increase in the value of the crop and decreasing the collect time and reducing wastes.

The developed mower was successful to harvest parsley leafs and transfer them to a collected box clean and well controlled. Testing the machine at different forward speeds and different conveyer speeds showed that the optimum conveyer linear speed for transfer parsley is $2.94-1.76 \mathrm{~m} / \mathrm{s}$.

Based on results of the present study, the developed mower may be used successfully for harvesting other leafy crops.

\section{REFERENCE:}

Central Administration for Agricultural Economics and Statistics, Ministry of Agriculture, Egypt, 2005 and 2009.

Celik, A. (2006). Design and operating characteristics of a push type cutter bar mower.Canadian biosystem engineering 48: 223-227.

El-Awady, M.N.; E.N. Mostafa; A.M. Gindy and E.A. Sahar (1988) "Design of an apparatus for measuring the resistance of plant stems for cutting" Misr J. Agric. Eng., (3) pp. 231-241.

El-Gindy, A. M., M. A Baiomy, M. M. Abdelhamed, And Mosa, Sahar, A.(2009). Design and fabrication of a simplified mechanical handling system of rice straw baling operation to reduce environment pollution. Misr J. Ag. Eng., 26(1): 667- 685

Hanna, G. B and Suliman, A. E. (1986). Appropriare harvesting equipment for small Egyptian farms Misr. J. Agric. Eng., 3 (1) pp. $58-72$

Hegazy, R. , G. Molari and A. M. El-Sheikha. (2011). Prototype of harvesting system for some aromatic and medical plants. International Journal of Agricultural Research 6 (5): 420-428.

Oida , A. (1997). Using personal computer for Agricultural machinery management. Kyoto University. Japan. JICA publishing. 
Ojomo, A. O., M. O. Ale and O. G. Olajide. (2010). development and performance evaluation of a cowpea harvester. ARPN Journal of Engineering and Applied Sciences. VOL. 5, NO. 10,

Rademaker, M. (2007). Parsley. New Zealand Dermatological Society Incorporated.

Shigley, J. E. and C. R. Mischke (2008) Mechanical engineering design. Me Graw- Hill Publishing Company. New York.

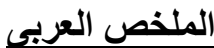

\section{تطوير أله لحصاد المحاصيل الورقية}

أ.د. سامى محمد يونس" ، د. محمد سيد عمران"، د. طارق حسين محمد"، م. مريم أحمد عامر؛ ".

تعتبر المحاصيل الورقيه من اهم المحاصيل التى تعتمد عليها الانسان فى غذاءه حيث انها تمد الجسم بإحتياجاته من البروتين وبعض الماتيه المواد العلاجيه وتعتبر مصدرا للعديد من الفيتامينات

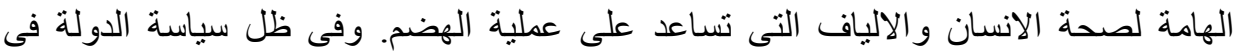

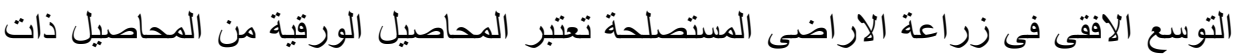

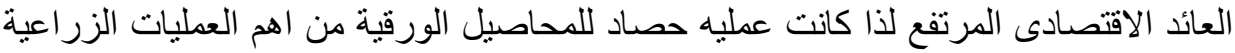

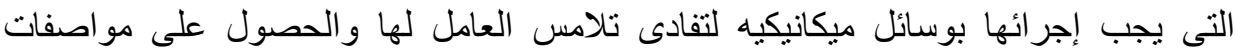

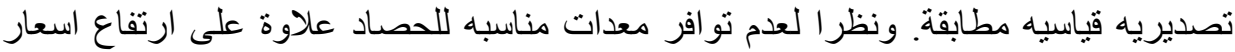

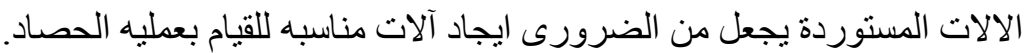

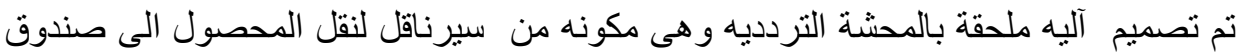

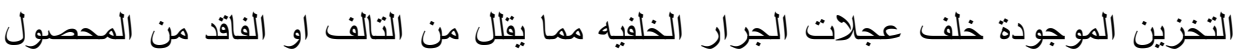

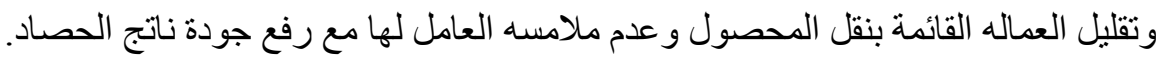

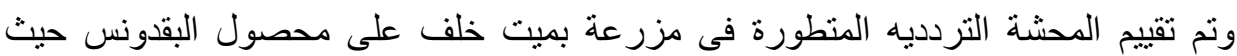

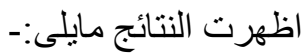
ا- بزيادة سرعة التقام للجرار يزداد معدل الأداء للمحشة زيادة واضحة مقارنة باقل سرعة

$$
\text { تقدم. }
$$

r- ت تزداد كفاءة القطع للبقدونس عندما تقل سر عة التقدم .

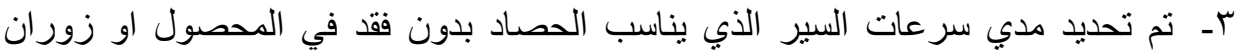

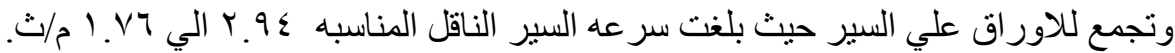

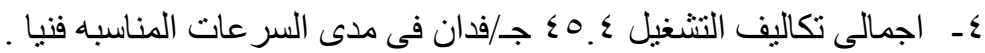

' استاذ الهندسة الزراعية ـ كليه الزراعة ـ جامعة القاهرة.

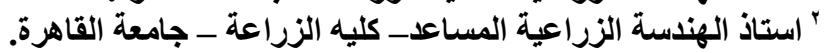

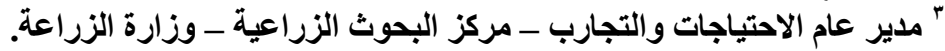

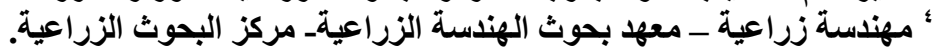

